Click www.researchjournal.co.in/online/subdetail.html to purchase.

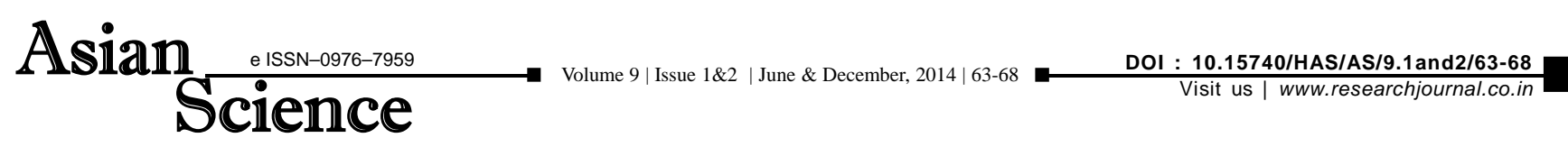

A REVIEW

\title{
Media portrayal of women
}

\section{DIPPANJEET KAUR* AND SHEETAL THAPAR}

Department of Agriculture Journalism, Languages and Culture, Punjab Agricultural University, LUDHIANA (PUNJAB) INDIA (Email: sheetal.pau@gmail.com)

\begin{abstract}
This article highlights some structures of social relations which influence the formation of images of women in society in the mass media. Media plays an important and vital role in women's empowerment and its development. Media can create an awakening inspiration to achieve their potential as prime source of change in the society, we live in. Media is considered as an important source in helping the women empowered. The media is considered as the most potent and influential mean in this regard as it has the capacity of persuading and moulding opinion. The relationship of the media and the women is important because whatever image women have in our country is influenced by media.
\end{abstract}

Key Words : Media portrayal of women, Women in media

View point paper : Kaur, Dippanjeet and Thapar, Sheetal (2014). Media portrayal of women. Asian Sci., 9 (1\&2): 63-68.

\footnotetext{
* Author for correspondence

Dippanjeet Kaur, Department of Agriculture Journalism, Languages and Culture, Punjab Agricultural University, LUDHIANA(PUNJAB) INDIA (Email: dippanpaulcobsajlc@pau.edu)
} 